\title{
Unraveling Causes and Consequences of International Retirement Migration to Coastal and Rural Areas in Mediterranean Europe
}

\author{
Gianluca Egidi ${ }^{1}$, Giovanni Quaranta ${ }^{2}{ }^{\circledR}$, Luca Salvati ${ }^{3, *}$, Filippo Gambella ${ }^{4}{ }^{\circledR}$, \\ Enrico Maria Mosconi ${ }^{5}{ }^{(0)}$, Antonio Giménez Morera ${ }^{6}$ and Andrea Colantoni ${ }^{1}{ }^{10}$ \\ 1 Department of Agricultural and Forestry Sciences (DAFNE), Tuscia University, Via San Camillo de Lellis, \\ I-01100 Viterbo, Italy; egidi.gianluca@unitus.it (G.E.); colantoni@unitus.it (A.C.) \\ 2 Department of Mathematics, Computer Science and Economics Department, University of Basilicata, \\ Viale dell'Ateneo Lucano, I-85100 Potenza, Italy; giovanni.quaranta@unibas.it \\ 3 Department of Economics and Law, University of Macerata, Via Armaroli 43, I-62100 Macerata, Italy \\ 4 Department of Agricultural Science, University of Sassari, Via De Nicola 9, I-07100 Sassari, Italy; \\ gambella@uniss.it \\ 5 Department of Economics, Engeneering, Society and Business, University of Tuscia, Via del Paradiso 47, \\ I-01100 Viterbo, Italy; enrico.mosconi@unitus.it \\ 6 Departamento de Economia y Ciencias Sociales, Universitat Politècnica de València, Cami de Vera S/N, \\ ES-46022 València, Spain; angimo1@doctor.upv.es \\ * Correspondence: luca.salvati@unimc.it; Tel.: +39-066-157-10; Fax: +39-066-157-1036
}

Received: 7 September 2020; Accepted: 23 October 2020; Published: 27 October 2020

\begin{abstract}
In a context of aging, low fertility, and progressive slowdown of both internal population mobility and international migration at working age, residential mobility at older ages was regarded as an emerging phenomenon in Mediterranean Europe, a region with increasingly attractive retirement places. The present work discusses the socioeconomic processes (and the environmental impacts) associated with an increasing flow of retirees, which decide to settle from 'Northern' countries to Southern Europe, concentrating in coastal districts and in rural countryside. Understanding lifestyle preferences and territorial patterns of residential mobility at older ages allows a refined analysis of short- and medium-term impacts of International Retirement Migration (IRM) on population dynamics in economically growing and declining regions. A refined analysis reveals that destinations of IRM are progressively enlarging from strictly coastal places to a broader set of locations in the rural countryside. Mobility choices among retirees may jeopardize the role of spatial planning, which is increasingly asked to provide specific services for an international, elder population, e.g., stimulating re-use of abandoned rural buildings. Taken as an effective option for rural development, an improved planning and management of local districts attracting and hosting intense flows of residential mobility at older ages is urgent in the present socioeconomic context. A convenient set of policies and a refined taxation system may contribute to reconcile demographic shrinkage with local competitiveness and social cohesion.
\end{abstract}

Keywords: retirees; population dynamics; rural development; Southern region

\section{Introduction}

Assuming the contribution of (increasing) movements of individuals, technology, and information to economic growth, broad-range mobility consolidated regional divides in urban and rural areas [1]. Characterization of socioeconomic and territorial factors shaping propensity and timing of migration may distinguish long-distance from short-distance moves [2], evidencing the attractive role of 
creative-cultural cities, coastal districts and traditional rural landscapes [3]. Salvati and Benassi [4] argued that "the spatial linkage between mobility and specific life course transitions has rarely been articulated and quantified. In these regards, gaps remain in our understanding of territorial patterns and socioeconomic processes characterizing spatial mobility with reference to both internal and international migration". In advanced economies, residential mobility has risen since the 1980s in response to socio-political factors that reflect globalization, rising opportunities for leisure movements and international experiences, accessibility, and higher flexibility of working lives, e.g., smart-working [5-8].

Being less intensively investigated [9-11], migration at older ages has important social implications and consequences, considering the influence that retirees have both in their countries of origin and destination [12-14]. Mobility at older ages delineates a sort of 'residential migration', responding to an increasing demand of 'self-fulfillment' or a 'good life' after retirement $[6,15,16]$. In these regards, retirees have displayed an intense amenity-driven spatial mobility seeking for a better quality of life in attractive locations with e.g., natural, cultural or tourism amenities $[12,14,17]$.

In Europe, a more extensive process of retirement migration was traced back to the 1992 Maastricht Treaty, which granted European citizens with free movements within the member states, giving the chance to export individual rights to healthcare and social security schemes [18-21]. It was demonstrated how the opportunity of free movements within the Union countries has largely stimulated residential mobility at both working and older ages [22-24]. As a result, specific regions developing 'retirement settlements' have emerged in Europe, especially in Mediterranean Europe, because the bulk of such movements was directed from Northern 'cold' countries to Southern 'warm' places [25].

The notion of 'International Retirement Migration' (IRM) was originally defined in reference to retirees living in Northern European countries who decide to move (seasonally or permanently) to Mediterranean Europe, considering individuals that have migrated both before and after retirement. Northern European retirees have been also defined as "residential tourists" or "lifestyle movers" [20,26,27]. According to Williams et al. [12], "IRM is a significant feature of the changing map of Europe. It has important implications in terms of the redistribution of both health care and social costs, and incomes and wealth". Because of favorable weather conditions over the whole year [22,28,29], Portugal, Spain and, partly, Italy, Greece, Croatia, Malta and Cyprus, include attractive locations for people in retirement ages from Western, Northern, and Central European countries [12,20,24,30-32]. An increasing flow of retired migrants from Great Britain to Southern Europe has been documented over recent decades [33]. Mediterranean places have been considered particularly attractive also because of the lower cost of living [18,34-36]. For instance, Algarve in Portugal, Costa del Sol in Spain, Malta and Tuscany in Italy have been considered, since the early 1990s, as preferential locations of British retirees moving to Southern Europe [12].

Four profiles of retired migrants have been identified in Europe [20,37,38]: (i) individuals (or families) transforming from 'being tourists' to 'being residents', where the main reason for emigration was the improvement of their quality of life because of better climate and lower costs of living; (ii) people working and thus being retired in the destination country; (iii) people retired in their country of origin and regrouped with their sons (or relatives) in the destination country; and (iv) individuals moving to Mediterranean countries to enter a cheaper community for elder people compared with prices in the country of birth or pristine residence [39-41]. Especially in coastal districts, natural growth of population and immigration at working and older ages fueled a continuous expansion of residential settlements, with the consequent development of small, contiguous land plots [42-44]. Retired people from United Kingdom resettling in Southern Spain demanded mixed housing typologies $[18,20,45,46]$. In Alicante, a Mediterranean coastal province of Spain close to Valencia, the real estate bubble of the 2000s and the intense flow of European foreigners altered significantly the urban outline, since most development took place on low-priced land in less-developed districts. At the same time, the most affluent settlements-partly developed in the recent past—expanded even more rapidly $[21,47,48]$. 
Based on a literature review, the present commentary focuses on the specific issue of IRM, (i) defining how this kind of spatial movements is targeted in different European economic contexts and (ii) delineating social profiles of retired people migrating (permanently or temporarily) in other places for a sufficiently long time period. Literature review was carried out inspecting the results of a specific search (using 'international retirement migration'-and similar nouns-as a basic keyword) on scientific databases including SCOPUS (Elsevier) and Google Scholar. Understanding the intrinsic motivations at the base of residential mobility allows a better investigation of location and housing preferences, clarifying the latent demographic and environmental implications of this rather complex and unpredictable phenomenon.

A better assessment of IRM through analysis of official statistics finally contributes to delineate a refined profile of retired workers with medium-long range of residential movements across countries. In this regard, it was discussed how long-range mobility and residential choices of retirees may influence spatial planning, which is urgently required to offer services for an elder population. Reconciling demographic dynamics with a convenient set of social policies and a revised taxation system is an important task with the final objective of regulating and governing more intense migration inflows at older ages. Spatial planning should also promote specific measures directed to satisfy the demand of retirees at older ages for housing, stimulating e.g., re-use (or renewal) of (abandoned) building stocks, especially in rural districts.

\section{Residential Mobility at Older Ages in Mediterranean Europe: A Brief Overview}

A significant part of migrant inflow in Mediterranean countries consisted of retired people and represents a multi-disciplinary investigation issue for migration studies, social policy and regional planning [8]. For instance, nearly $30 \%$ of the inhabitants in the age of 75 years and more in Canary Islands are retirees from other European countries [34]. Based on the empirical results of earlier studies [18,20,21,45-48], some classical 'Southern Hotspots' attracting retiree migrants from Northern Europe are shown in Figure 1. The Mediterranean coast of Spain was demonstrated to be one of the most attractive destinations for this type of immigration all over Europe. The inflow of retired immigrants in Spain grew since the early 1960s, and retired foreigners have continuously fueled population growth in both coastal and rural, most accessible, districts within the country [37].

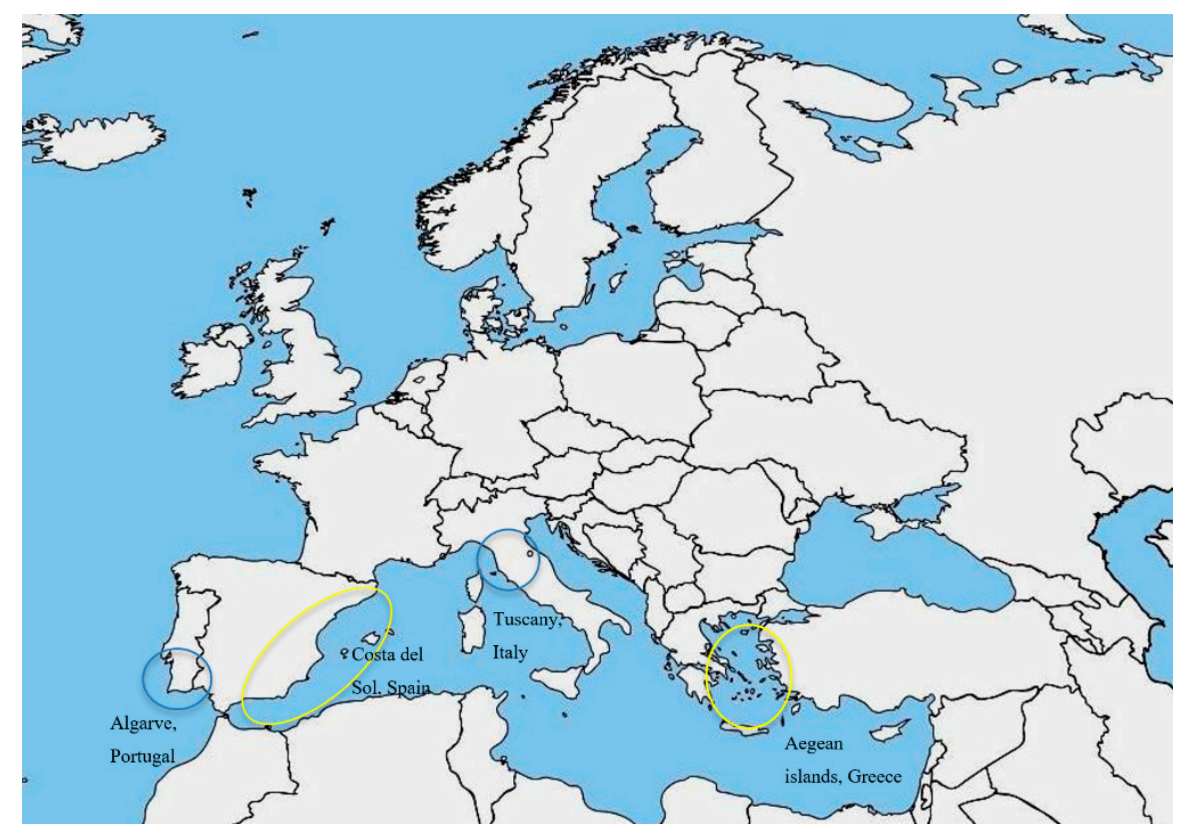

Figure 1. Selected Mediterranean hotspots attracting international retirement migration. 
Residential tourism at older ages intensified in the 1980s, when many Northern European retirees-from United Kingdom, Sweden, Germany and, partly, France-moved their residence in Southern places after visiting them once as tourists [16,49,50]. In the early 1990s, Mediterranean Spain (including Canary and Balearic Islands) recorded an even increasing inflow of European retirees [51]. Nowadays, about 190 thousand people older than 65 years settled-permanently or temporarily-in Spanish coastal municipalities, coming from different European countries [37]. Among them, 43\% were British native, and 14\% were German native. Warm and dry climate, moderate language barriers, a local culture of hospitality and wellbeing, traditions and food, cheap housing, and extensive provision of services for elders were at the base of the expansion and consolidation of such process, e.g., in Iberia [16]. Even in the most recent years, Spain was the leading country in Europe for the total amount of immigration flows at older ages from other European countries (Table 1). France and Italy respectively occupied the second and third positions in this special rank of countries hosting migrants at older ages. However, compared with the demographic size of Italy, Portugal and even Croatia displayed more intense (relative) inflows.

Table 1. Immigration flow (absolute numbers) of people 65+ years old with EU-28 citizenship (except the reporting country), by selected countries of citizenship in Europe and year (Mediterranean countries are represented in bold).

\begin{tabular}{cccccc}
\hline Country & $\mathbf{2 0 1 4}$ & $\mathbf{2 0 1 5}$ & $\mathbf{2 0 1 6}$ & $\mathbf{2 0 1 7}$ & $\mathbf{2 0 1 8}$ \\
\hline Spain & $\mathbf{8 . 1 6 6}$ & $\mathbf{8 . 3 6 3}$ & $\mathbf{9 . 6 2 3}$ & $\mathbf{1 1 . 2 8 2}$ & $\mathbf{1 2 . 6 8 2}$ \\
Germany & 4.913 & 5.405 & 5.188 & 5.463 & 5.471 \\
France & $\mathbf{4 . 6 3 8}$ & $\mathbf{4 . 3 6 8}$ & $\mathbf{4 . 9 1 0}$ & $\mathbf{4 . 1 6 7}$ & $\mathbf{4 . 5 8 0}$ \\
Poland & 3.364 & 2.055 & 1.763 & 3.023 & 2.180 \\
Switzerland & 1.920 & 1.710 & 1.492 & 1.211 & 1.169 \\
Italy & $\mathbf{1 . 7 7 0}$ & $\mathbf{1 . 8 3 6}$ & $\mathbf{1 . 9 5 8}$ & $\mathbf{2 . 1 5 9}$ & $\mathbf{2 . 4 2 4}$ \\
Hungary & 1.126 & 1.088 & 1.063 & 1.133 & 1.144 \\
Belgium & 1.068 & 1.078 & 1.159 & 1.135 & 1.124 \\
Luxembourg & 627 & 543 & 383 & 349 & 306 \\
Sweden & 572 & 609 & 594 & 572 & 532 \\
Portugal & $\mathbf{4 7 4}$ & $\mathbf{7 3 4}$ & $\mathbf{7 6 6}$ & $\mathbf{8 8 0}$ & $\mathbf{8 2 7}$ \\
Croatia & $\mathbf{3 6 6}$ & $\mathbf{3 4 5}$ & $\mathbf{3 3 9}$ & $\mathbf{3 5 0}$ & $\mathbf{4 1 5}$ \\
Netherlands & 356 & 421 & 391 & 512 & 518 \\
Czechia & 275 & 305 & 662 & 338 & 341 \\
Bulgaria & 221 & 225 & 197 & 93 & 178 \\
Norway & 210 & 134 & 152 & 121 & 141 \\
Denmark & 176 & 166 & 162 & 170 & 181 \\
Cyprus & $\mathbf{1 4 6}$ & $\mathbf{1 9 0}$ & $\mathbf{1 1 7}$ & $\mathbf{1 8 7}$ & $\mathbf{1 2 2}$ \\
Finland & 84 & 78 & 85 & 82 & 81 \\
Slovakia & 56 & 85 & 93 & 64 & 75 \\
Lithuania & 28 & 9 & 22 & 34 & 26 \\
Latvia & 20 & 28 & 26 & 37 & 43 \\
Iceland & 17 & 17 & 16 & 25 & 22 \\
Liechtenstein & 13 & 22 & 14 & 10 & 6 \\
Estonia & 5 & 127 & 110 & 149 & \\
\hline
\end{tabular}

Source: Eurostat; data not available for Greece, Malta and Slovenia.

Although Italy as a whole seems to be a less attractive destination for retired migrants from Northern Europe compared with Spain, and probably Southern France, Tuscany region in Central Italy is still considered one of the most selected locations in Mediterranean Europe. This was likely due to a particularly rich cultural heritage, historical urban centers, and flourishing rural areas, which are home to a large number of wealthy and well-educated retirees from e.g., United Kingdom [52]. Together with other similar districts in other countries, such as Provence in France [53], Tuscany locations offer landscapes of exceptional beauty and ways of life which fit the 'ideal' bourgeoisie traditions of a lost—while highly desirable—rurality, although remaining in the middle of Europe [54]. While in 
Spain, coastal districts are the most attractive locations for IRM thanks to high accessibility, public services, climate amenities and a long tradition of hospitality and tourism, rural districts in Italy seem to assure another dimension of life to retirees searching for a 'diffused rurality' instead of the 'beach and sun' model [35].

In Portugal, nearly 35\% of Algarve's foreign residents are non-native European citizens, mostly British (35\%) and German (15\%). Both permanent and seasonal inhabitants lived in rural areas few kilometers inland. Residential settlements along the sea coast included second homes and investment properties released to short-stay tourists [12]. A new taxation system was approved within the framework of the National Decree-Law No. 249/2009, delineating the notion of "Non-habitual Residents" ("Nao Residente Habitual"). This measure introduced an extensive tax exemption attracting retirees with foreign citizenship that covers a time period of 10 years. Older migrants were therefore stimulated to move - at least temporarily - their residence in Portugal, since the fiscal regime was intended to offer a full tax exemption on passive income earned outside the country and a flat rate of $20 \%$ for high value-added activities over a longer period. Although providing optimal conditions for those people seeking low tax jurisdictions, this regime has been less positively evaluated from other perspectives. For instance, tax benefits and lower costs for citizenship acquisition have been associated with more reasonable property prices because of real estate deflation in central cities, compared with other European metropolises [55].

In Greece, empirical findings from earlier studies [4] demonstrate how coastal districts were particularly attractive for incoming European residents-especially at older ages-representing more than $5 \%$ of the total resident population in some municipalities (Figure 2). This settlement pattern was in some way similar to the Spanish 'sun and beach' model, although with a significantly lower intensity of migration. By considering economic and population dynamics over a broader time interval, the same study documented a decline in the number of European immigrants in Greece immediately after the 2007 recession. Retirees (60+ years old) were the only exception to this trend all over the country (Table 2).

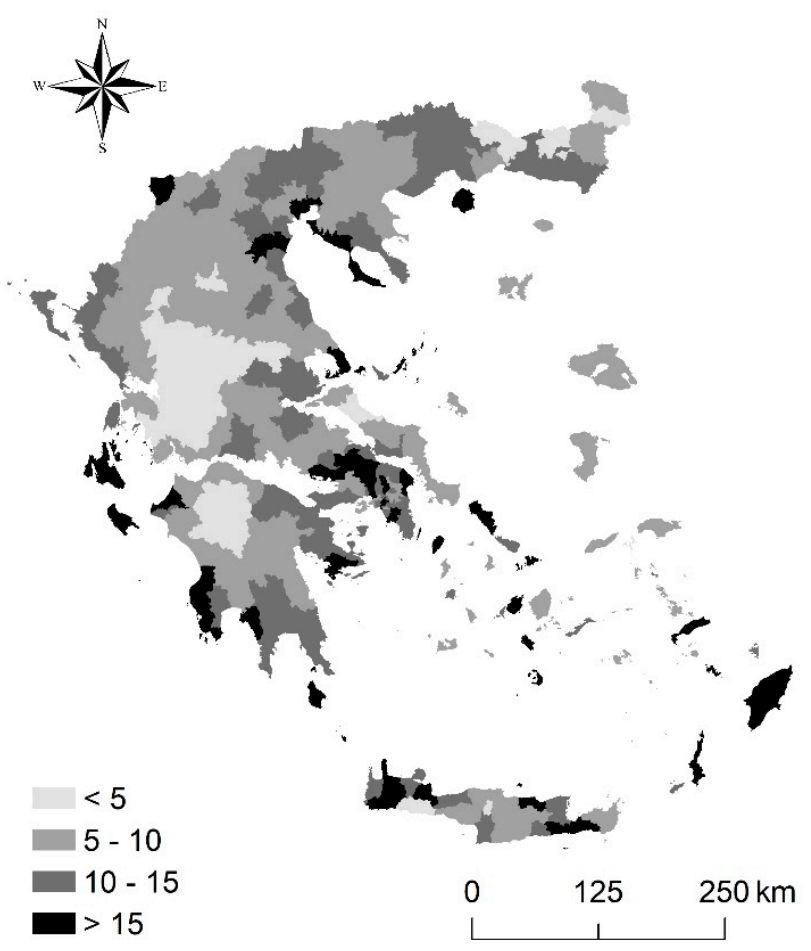

Figure 2. Per cent share of resident inhabitants in total resident population born abroad and resident in a given Greek municipality at 2011 census. 
Table 2. Descriptive statistics on incoming residents in Greece by year and age.

\begin{tabular}{ccccc}
\hline \multirow{2}{*}{ Year } & \multicolumn{2}{c}{ Inflows from Abroad (Absolute Numbers) } & \multicolumn{2}{c}{$\begin{array}{c}\text { Per Cent Share of }>\text { 60 Years } \\
\text { EU Incoming Residents in Total } \\
\text { EU Incoming Residents }\end{array}$} \\
\cline { 2 - 4 } & $\begin{array}{c}\text { Incoming } \\
\text { Residents }\end{array}$ & $\begin{array}{c}\text { With EU } \\
\text { Citizenship }\end{array}$ & $\begin{array}{c}\text { 60 Years } \\
\text { and above }\end{array}$ & 4.9 \\
\hline 2008 & 66.529 & 11.638 & 565 & 5.9 \\
2009 & 58.613 & 12.205 & 718 & 7.1 \\
2010 & 60.462 & 12.732 & 906 & 7.4 \\
2011 & 60.089 & 12.945 & 953 & 7.2 \\
2012 & 58.200 & 14.451 & 1.042 & 7.2 \\
2013 & 57.946 & 15.056 & 1.084 & 8.8 \\
2014 & 59.013 & 16.043 & 1.407 & 8.8 \\
2015 & 64.446 & 16.572 & 1.454 & 8.9 \\
2016 & 116.867 & 16.706 & 1.480 & 8.9 \\
2017 & 112.247 & 17.261 & 1.523 & 7.5 \\
2018 & 119.489 & 19.052 & 1.425 & \\
\hline
\end{tabular}

Source: ELSTAT, National Statistical Authority of Greece.

Being mostly self-financed at least up to the 1970s, and supported by household savings in the self-built informal sector, housing has been an influential factor shaping IRM in Greece. The property transfer tax, formally abolished in 1984, caused additional rigidity in the housing market, discouraging international mobility at older ages at the first stages. Increasing disparities among wealthy and disadvantaged locations resulted in polarized social structures, reflecting specific patterns of spatial mobility, and lowered the intrinsic attractiveness of such locations for international retirees, also because of the linguistic barrier. Especially marginal inland regions-despite natural amenities, cultural heritage, traditional social values, and particularly low housing prices-have experienced limited social permeability to retirees from abroad, displaying important territorial constraints (e.g., accessibility, services) for older migrants [56].

\section{Rural Landscapes and Economic Implications of IRM}

Earlier studies have examined the inherent changes in agricultural landscapes and farm buildings in Southern Europe [57,58], e.g., aimed at improving quality and sustainability of rural settlement systems [59]. Traditional farm buildings own a vital role in such landscapes [60-62], since they represent a characteristic heritage reflecting rural life, local uniqueness and sense of place [63]. In this regard, re-use of rural houses and buildings for different destinations including tourist sites, like often realized with e.g., wine cellars in some vineyard landscapes [62], has positive implications for rural districts, promoting new economic activities and containing population shrinkage [64].

A permanent monitoring of traditional rural buildings in Mediterranean peri-urban regions indicates a long-term human pressure owing to (more or less) recent processes of real estate speculation, industrialization, agricultural intensification and land abandonment [41]. Similar socioeconomic processes were observed in different countries, from Italy to Spain, from Portugal to Greece. Recent socioeconomic transformations resulted in (i) fragmented rural (non-farm) landscapes with over-diffused low-density settlements; (ii) a simplification of the agricultural landscape (e.g., olive groves, vineyards, orchards) mostly in lowlands and coastal districts; (iii) homogenization of relict natural landscapes - mostly protected and spatially concentrated in less accessible districts; (iv) a rapid expansion of shrub land, pastures, fallow land and abandoned meadows paralleling depopulation in mountain district $[65,66]$. Without effective monitoring and conservation measures, these processes may result in soil degradation, loss of ecosystem functions and biodiversity, as well as landscape aesthetic deterioration. Various forms of non-native human pressure, including IRM [22,33,67], residential tourism [68-70], second-home tourism [20,71,72], and lifestyle migration [6,73-75] have been regarded as drivers of change in rural landscapes. 
Residential tourism unfavorably affected pre-existing economic sectors using farmland for constructions and high buying power of residential tourists increased land and property prices in these regions [76]. Buying or renting a property in the destination country was particularly common among foreign retirees, assuring a demanded mobility to move back and forth [72]. A part of this population segment, the so called 'seasonal visitors', usually spent only a short time (no more than 1-2 months) in the destination country, e.g., owing to weather circumstances in the home country [29]. A large part of foreign retirees, however, remained in the destination country for a longer time, usually more than 4 months, far away from the standard definition of 'tourists' [77]. In this case, growing longevity and healthcare facilities, high income from pension and personal wealth, and a 'more active' aging style were regarded as important factors fueling spatial mobility at older ages, especially from Northern European countries [78]. Retirees' destinations basically include two typologies of settlements: (i) coastal districts, with clustered-and sometimes highly segregated—settlements formed of large villas with gardens and residential swimming pools [14], and (ii) rural areas of exceptional landscape value, with isolated houses having a characteristic small piece of land to crop with horticulture, orchards, olives or vineyards [12]. Costa del Sol in Spain and Tuscany in Italy (Figure 3) are examples of these two settlement types [49].

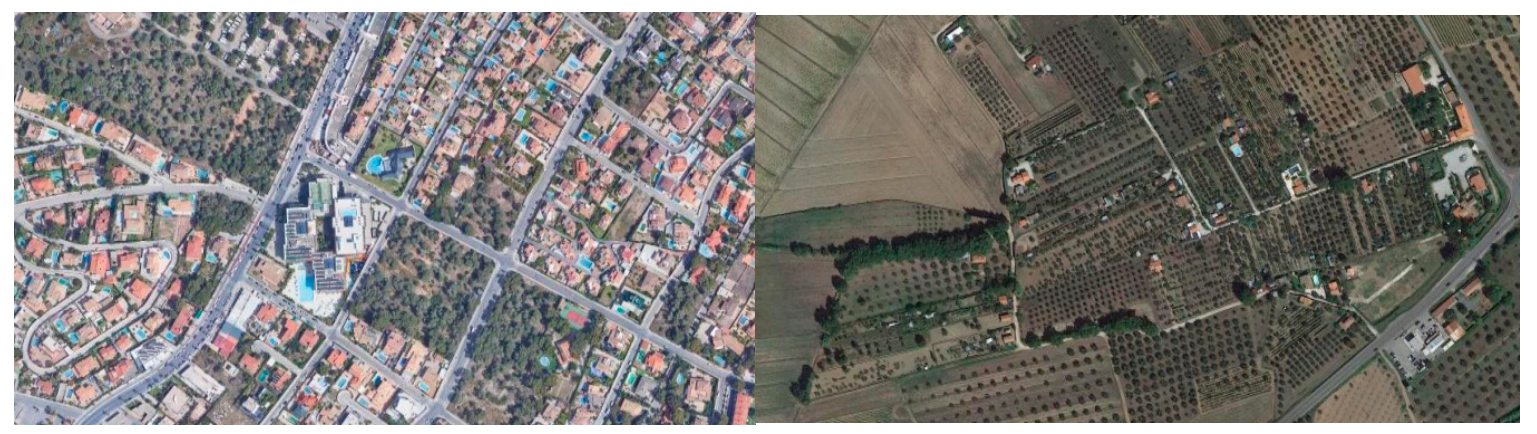

Figure 3. Typical settlements hosting international migrants at retirement age in coastal Spain (left) and Tuscany, Italy (right).

The individual preference toward rural landscapes reveals a strong demand for 'southern and warmer' regions, but also for contexts with stable political systems and more transparent legal frameworks regulating property transactions. In such areas, in coastal Spain as in Southern France [79], retirees have been demonstrated to contribute to changes in rural settlements, shaping demand for housing and requirement for collective facilities [49]. More specifically, IRM has strengthened current demographic structures stimulating a sort of 'spatial life course' development [80]. In such contexts, retired immigrants settling in countryside locations are key actors of 'rural revitalization' and, in some cases, of a more subtle 'rural gentrification'. In these regards, the French countryside has been increasingly transformed as far as housing structures are concerned, with foreign retirees being increasingly involved in such process [81].

The ineffectiveness of spatial planning, partly because of a persistent culture of 'spontaneity' and 'deregulation' in some Mediterranean regions-especially Greece, Southern Italy and more limited areas of Spain and Portugal-may threaten ecological quality and scenic beauty of these relict landscape systems, negatively impacting the well-being of resident population, including retirees from abroad. Based on this framework, environmental policy is increasingly asked to consider cultural and human dimensions in a broader strategy preserving the natural component of rural landscapes. A sustainable management of rural landscapes should incorporate specific strategies protecting environmental and cultural heritage together with the local communities and traditions. An effective management of migration processes at older ages should be included in such a strategy, improving the attractiveness of places while reducing the consequent human pressure [82]. 
As far as Italy, retirees who moved to Southern regions, settling in a rural municipality with less than 20 thousand inhabitants, have been entitled to receive extensive tax discounts since 2020, e.g., a flat rate of $7 \%$ on personal revenues. This regulation is assumed to have a positive impact for revitalization of small Italian villages, leveraging a territorial re-balance between Northern (affluent) regions and Southern (disadvantaged) districts [83]. Similarly to what has happened in Portugal, the impact of such favorable fiscal regime on population dynamics and resilience of local communities, needs specific investigation based on reliable statistical data [69].

\section{Discussing the Spatial Implications of Residential Mobility at Older Ages}

Earlier studies have focused on the reasons underlying the choice of elder people to move abroad, following approaches that refer to specific theories dealing with retirement [22], lifestyles [7], and social networks [34]. Assuming a life cycle approach ensuing specific factors of individual needs in terms of housing place and dwelling type [84-86], individual-level variables and life course events exert a significant impact on the probability of later life mobility [87-89]. Despite the increasing opportunities for free movements from Northern to Southern Europe, evident socioeconomic disparities-within and among origin and destination countries-keep on unrestricted [90]. Unequal working (and retirement) conditions and chances for future mobility persist within a dividing context of privatization and shrinking public provision across Europe, adding to the inherent impact of economic recession and austerity measures in Mediterranean countries [27]. For instance, the moderate cost of living, based on low housing costs and favorable taxation regimes [12], is a less important dimension fueling IRM in Central Italy (e.g., in Tuscany), or in Southern France (e.g., Provence), where the cost of living is roughly aligned with the United Kingdom [83]. This aspect, however, may have a role boosting IRM to other Mediterranean destinations, including Malta, Croatia, Cyprus, Greece, Portugal, Southern Spain, or Turkey [36].

Assuming that foreign (elder) population still boosts residential growth-e.g., promoting second-home settlements and specific housing typologies in small land plots along the sea coast and in rural countryside, recent studies stimulate a rethinking of the role of spatial planning and developmental measures in local communities less organized to host enlarged inflows of retirees from Northern Europe. Being asked to provide services for a progressively elder population, social policies in Mediterranean countries should reconcile retirement migration with internal demographic dynamics and the specificity of local contexts, promoting finely tuned taxation systems and appropriate spatial infrastructures.

The spatial development of retirement populations within specific neighborhoods has significant implications for both migrants and host communities [91-93]. For instance, British communities in Tuscany prefer farmhouses, e.g., old farm buildings and other rural dwellings, but also urban settlements, including Florence, Pisa, Lucca and other smaller towns. Also in France, British communities frequently chose the farmhouse settlement type, having purchased old rural dwellings, many of which had been previously used as farm buildings [54,94,95]. Conversely, retiree migrants in Spain (e.g., in Costa del Sol) displayed a preference for newly built-up residential estates [41], where foreign residents have been numerically dominant [96]. More scattered individual villas-alimenting an omnipresent sprawl in rural fringes [97] - also emerged in coastal Spain, being less relevant in term of surface area [98]. In Greece, while immigration still plays a key role in fueling population growth-leading to a more balanced age structure in local communities exposed to aging and depopulation-IRM could in turn impact negatively population dynamics, with the consequent acceleration of aging processes in some rural districts [99].

These multifaceted settlement typologies are significant, in both theory and practice, from various points of view [100]. First, IRM adds a new complex dimension to the pre-existing settlement structure in coastal and rural districts, reinforcing the human impact of international tourism, residential mobility and second-home development on traditionally fragile landscapes. Second, the economic impact of retired migrants has been mainly assessed considering housing and personal consumption 
expenditures-which can be higher than those of natives thanks to major transfers of wealth and income during their working life in Northern Europe [4]. Irradiating from specific locations with high attractiveness, this impact was redesigning slowly the geography of settlement expansion in Europe. Third, IRM contributes to negatively impact health and welfare services [91]. Retirement migration is thus regarded as a relevant dimension of health services planning [38]. In these regards, social policy in destination countries should recognize the importance of aging care needs, which may differ between native inhabitants and foreign retirees owing to multiple factors that include linguistic/cultural barriers and, in most cases, the lack of a family assisting them [21].

As a general rule, spatial mobility reflects social, institutional and political transformations associated with lifestyle changes, economic downturns and metropolitan cycles [40,101,102]. Moreover, "the lifestyle of the baby boomers as retirees has been assumed to differ from older cohorts due to them being financially more stable and having grown up during the welfare state expansion" [103]. In these regards, international migration after retirement was a pivotal dimension shaping population dynamics in both urban and rural contexts of Southern Europe. Our commentary illustrates how, in recent decades, the opportunity to long-haul residential mobility-and especially North-South mobility-was leveraged by several factors at the continental, national and regional scale in Europe. Retiree citizens from Northern European countries who choose to live (permanently or temporarily) in a country of Southern Europe account for a large part of these movements [12,20,24,28,31,32,73]. Natural amenities, mild climate, lower housing prices, food and culture/local traditions, services and hospitality, as well as typical landscapes are major reasons to move $[7,18,26,28,33-36,54]$. In these regards, typical settlements, e.g., rural cottages or traditional (Medieval or Renaissance villages), are particularly attractive. These findings have clear implications for local communities and the built environment at large [96].

A comprehensive analysis of complex processes such as IRM needs a refined assessment framework based on integrated systems of official statistics derived from multiple data sources (demographic censuses, population and business registers, labor force and other sampling surveys). Definitions and operational practices dealing with such statistics should be shared at the supra-national scale [103-105]. While the coordination of Eurostat revealed to be effective, a broader integration of different informative sources among national statistical systems in Europe is still urgent. Integrated surveys represent the necessary knowledge base to design more appropriate indicators estimating IRM. Quantifying spatial direction and intensity of migration inflows at a local scale, also benefits from a better characterization of the socioeconomic profile of movers, shedding further light on the motivations underlying long-haul mobility at older ages. "Since conventional census-based measures of population mobility may ignore multiple moves-obscuring the diversification of human migration experiences-these indicators could be supplemented with data on movement frequency and residence duration indicating chronic mobility and significant differences between frequent movers and long-term stayers" [4].

Integrating macro-scale indicators derived from traditional survey-based procedures with individual-level mobility data and web-based network/telecommunication data can give a practical tool in this direction, providing operational solutions to such research needs [106-108]. Moreover, according to Salvati and Benassi [4], "a comprehensive understanding of locational choice of older movers may derive from a broader analysis of migration dynamics over time, distinguishing settlement preferences of younger and older migrants". Future studies should better investigate the intrinsic linkage between IRM and economic cycles, "giving a broader perspective on migration dynamics (considering together citizenship and age) and settlement preferences during both expansion and recession".

In these regards, "while migrants' location preferences may change over time, we assume that local context is a powerful attraction factor, whose strength may vary according with the economic phase, evidencing the joint role of space and economic cycle in shaping migration flows" [4]. The complex motivations at the base of IRM require further clarification and permanent assessment, being relevant to the analysis of residential mobility at older ages in the Mediterranean region [109-111]. Displaying different impacts according with the specific local context, IRM stimulated, for instance, 
scattered urbanization along coastal districts in Spain, leading to intense urban sprawl and land degradation $[41,96,112]$. Conversely, in some Italian or French countryside locations, rural settlements have been progressively reused and permanently occupied by retirees coming from Northern Europe $[21,55,69]$. Based on these premises, we can conclude that "spatial direction and intensity of population movements reflect complex socioeconomic transformations, whose knowledge provides innovative visions for a better understanding of future demographic dynamics in Mediterranean Europe" [4].

\section{Concluding Remarks}

Although delineating short-term demographic scenarios for the Northern Mediterranean region is a particularly hard task, it seems clear how IRM will remain an important part of long-haul residential mobility across Europe, being less sensitive to economic recessions and other external shocks than more traditional migration flows at working ages. How the recent COVID pandemic will redesign the geography of IRM across Europe is also a particularly interesting research issue, considering both positive and negative effects on migration flows. In these regards, continental-scale dynamics will add to national-scale patterns and more specific regional-scale contexts. For instance, Brexit-a legislation change based on a specific decision taken at the national scale in the United Kingdom-can have a broader-scale role shaping intensity of IRM toward Southern Europe. Considering the high contribution of UK retirees to IRM all over Mediterranean Europe, Brexit will reshape the spatial directions of migration flows at older ages in the coming 5-10 years. Based on these assumption, it is possible to hypothesize a reduction—likely not so intense-of migration inflows from UK and a slight increase of inflows from other member states of Northern Europe.

In a broader time interval, it could be interesting to focus on the specific behavior of retirees in Central-Eastern Europe, traditionally less attracted by Mediterranean locations for various geo-political, religious, economic and social motivations. In this perspective, the potential role of Greece and Cyprus as attractors of retirees from Balkan countries should be better investigated in light of a progressive improvement of average income and wealth conditions in such countries. At the same time, the role of Romania and Bulgaria as possible attractors of retirees from other countries of Eastern Europe should be also investigated in more details, considering the intrinsic similarities among countries, a progressively improved accessibility, less intense language barriers, and the increased attractiveness of coastal locations (especially along the Black Sea). Based on these considerations, a refined understanding of the implications of IRM for local population dynamics in the Mediterranean region, and in neighboring countries, is particularly urgent. In a context of increasingly low fertility and aging, measures managing IRM will definitely contribute to counteract demographic shrinkage of rural districts and an excessive human pressure in coastal areas.

Author Contributions: Conceptualization, L.S. and A.C.; methodology, G.Q. and G.E.; software, G.E. and A.G.M.; validation, A.G.M.; formal analysis, A.C. and E.M.M.; investigation, G.Q. and E.M.M.; resources, G.E. and E.M.M.; data curation, G.E. and A.C.; writing-original draft preparation, L.S. and G.Q.; writing-review and editing, A.C. and E.M.M.; visualization, G.E.; supervision, A.G.M. and F.G.; project administration, A.G.M. All authors have read and agreed to the published version of the manuscript.

Funding: This work received no funding.

Conflicts of Interest: The authors declare no conflict of interest.

\section{References}

1. Bell, M. How often do australians move? Alternative measures of population mobility. J. Aust. Popul. Assoc. 1996, 13, 101-124. [CrossRef] [PubMed]

2. Allen, J.; Barlow, J.; Leal, J.; Maloutas, T.; Padovani, L. Housing in Southern Europe; Blackwell: London, UK, 2004.

3. Alexandri, G.; Janoschka, M. Who Loses and Who Wins in a Housing Crisis? Lessons from Spain and Greece for a Nuanced Understanding of Dispossession. Hous. Policy Debate 2017, 28, 117-134. [CrossRef] 
4. Salvati, L.; Benassi, F. Rise (and Decline) of European Migrants in Greece: Exploring Spatial Determinants of Residential Mobility (1988-2017), with Special Focus on Older Ages. J. Int. Migr. Integr. 2020, 1-15. [CrossRef]

5. Müller, D.K. German Second Homeowners in the Swedish Countryside: On the Internationalization of the Leisure Space. Ph.D. Thesis, Department of Social and Economic Geography, Umeå University, Umeå, Sweden, 1999.

6. Benson, M.; O’Reilly, K. Lifestyle Migration: Expectations, Aspirations and Experiences; Ashgate: Aldershot, UK, 2009.

7. Gustafson, P. Your home in Spain: Residential Strategies in International Retirement Migration. In Lifestyle Migrations: Expectations, Aspirations and Experiences; Benson, M., O’Reilly, K., Eds.; Ashgate: Surrey, UK, 2009.

8. Hannonen, O. Second homeowners as tourism trend-setters: A case of residential tourists in Gran Canaria. J. Spat. Organ. Dyn. 2018, 6, 345-359.

9. Burholt, V. Transnationalism, economic transfers and families' ties: Intercontinental contacts of older Gujaratis, Punjabis and Sylhetis in Birmingham with families abroad. Ethn. Racial Stud. 2004, 27, 800-829. [CrossRef]

10. King, R.; Vullnetari, J. Orphan pensioners and migrating grandparents: The impact of mass migration on older people in rural Albania. Ageing Soc. 2006, 26, 783-816. [CrossRef]

11. Ramji, H. British Indians 'Returning Home': An Exploration of Transnational Belongings. Sociology 2006, 40, 645-662. [CrossRef]

12. Williams, A.M.; King, R.; Warnes, T. A place in the sun: International retirement migration from northern to southern Europe. Eur. Urban Reg. Stud. 1997, 4, 115-134. [CrossRef]

13. White, P. Migrant Populations Approaching Old Age: Prospects in Europe. J. Ethn. Migr. Stud. 2006, 32, 1283-1300. [CrossRef]

14. Parreño-Castellano, J.; Domínguez-Mujica, J. Working and retiring in sunny Spain: Lifestyle migration further explored. Hung. Geogr. Bull. 2017, 65, 407-420. [CrossRef]

15. Monfort, J.G.; Hall, K.; Betty, C. Back to Brit: Retired British migrants returning from Spain. J. Ethn. Migr. Stud. 2016, 42, 797-815. [CrossRef]

16. Oliver, C. Peer-Led Care Practices and 'Community' Formation in British Retirement Migration. Nord. J. Migr. Res. 2017, 7, 172. [CrossRef]

17. Paredes, D.; Redrobán, V. Retirement here or there? Ageing-migrants' transnational social protection strategies. In Boletin OEG de Investigación; European Observatory on Gerontomigration (OEG): Malaga, Spain, 2017; pp. 1-14.

18. O'Reilly, K. Intra-European Migration and the Mobility-Enclosure Dialectic. Sociology 2007, 41, $277-293$. [CrossRef]

19. Coldron, K.; Ackers, L. Using European Citizenship? EU Retired Migrants and the Exercise of Healthcare Rights. Maastricht J. Eur. Comp. Law 2007, 14, 287-302. [CrossRef]

20. Hall, K. Retirement migration and health: Growing old in Spain. In Handbook of Migration and Health; Elsevier: Amsterdam, The Netherlands, 2016; p. 402.

21. Hall, K.; Hardill, I. Retirement migration, the 'other' story: Caring for frail elderly British citizens in Spain. Ageing Soc. 2014, 36, 562-585. [CrossRef]

22. King, R.; Warnes, A.M.; Williams, A.M. Sunset Lives: British Retirement Migration to the Mediterranean; Berg: Oxford, UK, 2000.

23. Ackers, L.; Dwyer, P. Senior Citizenship? Retirement, Migration and Welfare in the European Union; Policy Press: Bristol, UK, 2002.

24. Muñoz, R.D. International retirees at the polls: Spanish local elections 2015. RIPS 2018, 17. [CrossRef]

25. Gustafson, P. Transnationalism in retirement migration: The case of North European retirees in Spain. Ethn. Racial Stud. 2008, 31, 451-475. [CrossRef]

26. O'Reilly, K. The British on the Costa del Sol: Transnational Identities and Local Communities; Routledge: London, UK, 2000.

27. Gavanas, A.; Calzada, I. Multiplex Migration and Aspects of Precarization: Swedish Retirement Migrants to Spain and their Service Providers. Crit. Sociol. 2016, 42, 1003-1016. [CrossRef]

28. Rodríguez, V.; Fernández-Mayoralas, G.; Rojo, F. European retirees on the Costa del Sol: A cross-national comparison. Int. J. Popul. Geogr. 1998, 4, 183-200. [CrossRef] 
29. Özyurt, P.M.; Başaran, M.A.; Kantarc1, K. Residential Tourists' Perceptions of Quality of Life: Case of Alanya, Turkey. Adv. Hosp. Tour. Res. 2018, 6, 147-168. [CrossRef]

30. Rodriguez, V.; Fernández-Mayoralas, G.; Rojo-Pérez, F. International Retirement Migration: Retired Europeans Living on the Costa Del Sol, Spain. Popul. Rev. 2004, 43, 1-36. [CrossRef]

31. Warnes, A. Older migrants in Europe: Essays, Projects and Sources; Sheffield Institute for Studies on Ageing: Sheffield, UK, 2004.

32. Carrasco, J.B.; Gil-Alonso, F. Suburbanisation and international immigration: The case of the Barcelona Metropolitan Region (1998-2009). Tijdschr. Econ. Soc. Geogr. 2011, 103, 312-329. [CrossRef]

33. Gustafson, P. Tourism and seasonal retirement migration. Ann. Tour. Res. 2002, 29, 899-918. [CrossRef]

34. Casado-Díaz, M.A.; Kaiser, C.; Warnes, A.M. Northern European retired residents in nine southern European areas: Characteristics, motivations and adjustment. Ageing Soc. 2004, 24, 353-381. [CrossRef]

35. Breuer, T. Retirement Migration or rather Second-Home Tourism? German Senior Citizens on the Canary Islands. Die Erde 2005, 136, 313-333.

36. Bolzman, C.; Kaeser, L.; Christe, E. Transnational mobilities as a way of life among older migrans from southern Europe. Popul. Space Place 2017, 23, e2016. [CrossRef]

37. Campos, R.A. Retirement Migration in Spain: Two Cases Studies in Catalonian and Mallorca. MOJ Gerontol. Geriatr. 2018, 3, 00072. [CrossRef]

38. Hall, C.M.; Müller, D.K. The Routledge Handbook of Second Home Tourism and Mobilities; Routledge: London, UK, 2018.

39. Incerti, G.; Feoli, E.; Salvati, L.; Brunetti, A.; Giovacchini, A. Analysis of bioclimatic time series and their neural network-based classification to characterise drought risk patterns in South Italy. Int. J. Biometeorol. 2006, 51, 253-263. [CrossRef]

40. Salvati, L.; Ciommi, M.T.; Serra, P.; Chelli, F.M. Exploring the spatial structure of housing prices under economic expansion and stagnation: The role of socio-demographic factors in metropolitan Rome, Italy. Land Use Policy 2019, 81, 143-152. [CrossRef]

41. Cuadrado-Ciuraneta, S.; Durà-Guimerà, A.; Salvati, L. Not only tourism: Unravelling suburbanization, second-home expansion and "rural" sprawl in Catalonia, Spain. Urban Geogr. 2017, 38, 66-89. [CrossRef]

42. Piga, A.; Gambella, F.; Vacca, V.; Agabbio, M.C.S. Response of three Sardinian olive cultivars to Greek-style processing. Ital. J. Food Sci. 2001, 13, 29-40.

43. Bayona-I-Carrasco, J.; Gil-Alonso, F. Is Foreign Immigration the Solution to Rural Depopulation? The Case of Catalonia (1996-2009). Sociol. Rural. 2012, 53, 26-51. [CrossRef]

44. Bonifazi, C.; Heins, F. Long-term trends of internal migration in Italy. Int. J. Popul. Geogr. 2000, 6, 111-131. [CrossRef]

45. Dieleman, F.M. Modelling residential mobility; a review of recent trends in research. Neth. J. Hous. Environ. Res. 2001, 16, 249-265.

46. Oliver, C. Retirement Migration: Paradoxes of Ageing; Routledge: London, UK, 2008.

47. Hardill, I.; Spradbery, A.; Arnold-Boakes, J.; Marrugat, M.L. Severe health and social care issues among British migrants whore tire to Spain. Ageing Soc. 2005, 25, 769-783. [CrossRef]

48. Morote, Á.F.; Sauri, D.; Hernández, M. Residential Tourism, Swimming Pools, and Water Demand in the Western Mediterranean. Prof. Geogr. 2016, 69, 1-11. [CrossRef]

49. Warnes, A.M.; Williams, A. Older Migrants in Europe: A New Focus for Migration Studies. J. Ethn. Migr. Stud. 2006, 32, 1257-1281. [CrossRef]

50. Olsson, E.; O'Reilly, K. North-Europeans in Spain: Practices of community in the context of migration, mobility and transnationalism. Nord. J. Migr. Res. 2017, 7, 133-138. [CrossRef]

51. Gavanas, A. Swedish Retirement Migrant Communities in Spain: Privatization, informalization and moral economy filling transnational care gaps1. Nord. J. Migr. Res. 2017, 7, 165-171. [CrossRef]

52. Ernsten, A.; Mccollum, D.; Feng, Z.; Everington, D.; Huang, Z. Using linked administrative and census data for migration research. Popul. Stud. 2018, 72, 357-367. [CrossRef]

53. Williams, A.M.; King, R.; Warnes, A.; Patterson, G. Tourism and international retirement migration: New forms of an old relationship in southern Europe. Tour. Geogr. 2000, 2, 28-49. [CrossRef]

54. Buller, H.; Hoggart, K. International Counterurbanization: British Migrants in Rural France; Aldershot: Avebury, UK, 1994. 
55. Montezuma, J.; McGarrigle, J. What motivates international homebuyers? Investor to lifestyle 'migrants' in a tourist city. Tour. Geogr. 2018, 21, 214-234. [CrossRef]

56. Ciommi, M.; Gigliarano, C.; Emili, A.; Taralli, S.; Chelli, F.M. A new class of composite indicators for measuring well-being at the local level: An application to the Equitable and Sustainable Well-being (BES) of the Italian Provinces. Ecol. Indic. 2017, 76, 281-296. [CrossRef]

57. Tassinari, P.; Torreggiani, D.; Benni, S. Dealing with agriculture, environment and landscape in spatial planning: A discussion about the Italian case study. Land Use Policy 2013, 30, 739-747. [CrossRef]

58. Torreggiani, D.; Tassinari, P. Landscape quality of farm buildings: The evolution of the design approach in Italy. J. Cult. Heritage 2012, 13, 59-68. [CrossRef]

59. Russo, P.; Tomaselli, G.; Pappalardo, G. Marginal periurban agricultural areas: A support method for landscape planning. Land Use Policy 2014, 41, 97-109. [CrossRef]

60. Cánoves, G.; Villarino, M.; Priestley, G.K.; Blanco, A. Rural tourism in Spain: An analysis of recent evolution. Geoforum 2004, 35, 755-769. [CrossRef]

61. Cañas, I.; Ayuga, E.; Ayuga, F. A contribution to the assessment of scenic quality of landscapes based on preferences expressed by the public. Land Use Policy 2009, 26, 1173-1181. [CrossRef]

62. Fuentes, J.; Gallego, E.; García, A.; Ayuga, F. New uses for old traditional farm buildings: The case of the underground wine cellars in Spain. Land Use Policy 2010, 27, 738-748. [CrossRef]

63. Coeterier, J. Dominant attributes in the perception and evaluation of the Dutch landscape. Landsc. Urban Plan. 1996, 34, 27-44. [CrossRef]

64. Ranca, A.; Braduceanu, D.; Mihailescu, F.; Popescu, M. Wines routes in Dobrogea: Solution for a sustainable development of the local agrotouristic potential. J. Environ. Prot. Ecol. 2007, 8, 591-596.

65. Kabisch, N.; Haase, D. Diversifying European agglomerations: Evidence of urban population trends for the 21st century. Popul. Space Place 2011, 17, 236-253. [CrossRef]

66. Geeson, N.; Quaranta, G.; Salvia, R.; Brandt, J. Long-term involvement of stakeholders in research projects on desertification and land degradation: How has their perception of the issues changed and what strategies have emerged for combating desertification? J. Arid. Environ. 2015, 114, 124-133. [CrossRef]

67. Croucher, S. Privileged Mobility in an Age of Globality. Societies 2012, 2, 1-13. [CrossRef]

68. Mazón, T. Inquiring into residential tourism: The Costa Blanca case. Tour. Hosp. Plan. Dev. 2006, 3, 89-97. [CrossRef]

69. Holleran, M. Residential tourists and the half-life of European cosmopolitanism in post-crisis Spain. J. Sociol. 2016, 53, 217-230. [CrossRef]

70. Oliveira, C.; Brochado, A.; Correia, A. Seniors in international residential tourism: Looking for quality of life. Anatolia 2017, 29, 11-23. [CrossRef]

71. Müller, D.K. Reinventing the Countryside: German Second-home Owners in Southern Sweden. Curr. Issues Tour. 2002, 5, 426-446. [CrossRef]

72. Hall, C.M. Second Home Tourism: An International Review. Tour. Rev. Int. 2014, 18, 115-135. [CrossRef]

73. Findlay, A.M.; Mccollum, D.; Coulter, R.; Gayle, V. New Mobilities Across the Life Course: A Framework for Analysing Demographically Linked Drivers of Migration. Popul. Space Place 2015, 21, 390-402. [CrossRef]

74. Torkington, K. Place and Lifestyle Migration: The Discursive Construction of 'Glocal' Place-Identity. Mobilities 2012, 7, 71-92. [CrossRef]

75. Cohen, S.A.; Duncan, T.; Thulemark, M. Lifestyle Mobilities: The Crossroads of Travel, Leisure and Migration. Mobilities 2013, 10, 155-172. [CrossRef]

76. Gascón, J. Residential tourism and depeasantisation in the Ecuadorian Andes. J. Peasant. Stud. 2015, 43, 868-885. [CrossRef]

77. Zontini, E. Growing old in a transnational social field: Belonging, mobility and identity among Italian migrants. Ethn. Racial Stud. 2014, 38, 326-341. [CrossRef]

78. Gavalas, V.S.; Rontos, K.; Salvati, L. Who Becomes an Unwed Mother in Greece? Sociodemographic and Geographical Aspects of an Emerging Phenomenon. Popul. Space Place 2014, 20, 250-263. [CrossRef]

79. Kasimis, C. Survival and expansion: Migrants in Greek rural regions. Popul. Space Place 2008, 14, 511-524. [CrossRef]

80. Vollet, D.; Callois, J.-M.; Roussel, V. Impact of retirees on rural development: Some observations from the South of France. J. Reg. Anal. Policy 2005, 35, 54-74. 
81. Longino, C.F.; Perzynski, A.T.; Stoller, E.P. Pandora's Briefcase: Unpacking the Retirement Migration Decision. Res. Aging 2002, 24, 29-49. [CrossRef]

82. Vos, W.; Meekes, H. Trends in European cultural landscape development: Perspectives for a sustainable future. Landsc. Urban Plan. 1999, 46, 3-14. [CrossRef]

83. Dwyer, P.J. Movements to some purpose? An exploration of international retirement migration in the European Union. Educ. Ageing 2000, 15, 353-377.

84. Kim, T.-K.; Horner, M.W.; Marans, R.W. Life Cycle and Environmental Factors in Selecting Residential and Job Locations. Hous. Stud. 2005, 20, 457-473. [CrossRef]

85. Sabater, A.; Graham, E.; Finney, N. The spatialities of ageing: Evidencing increasing spatial polarisation between older and younger adults in England and Wales. Demogr. Res. 2017, 36, 731-744. [CrossRef]

86. Marois, G.; Lord, S.; Negron-Poblete, P. The Residential Mobility of Seniors Among Different Residential Forms: Analysis of Metropolitan and Rural Issues for Six Contrasted Regions in Québec, Canada. J. Hous. Elder. 2017, 32, 73-98. [CrossRef]

87. Walters, W.H. Later-Life Migration in the United States: A Review of Recent Research. J. Plan. Lit. 2002, 17, 37-66. [CrossRef]

88. Sergeant, J.F.; Ekerdt, D.J. Motives for Residential Mobility in Later Life: Post-Move Perspectives of Elders and Family Members. Int. J. Aging Hum. Dev. 2008, 66, 131-154. [CrossRef] [PubMed]

89. Riley, A.; Hawkley, L.C.; Cagney, K.A. Racial Differences in the Effects of Neighborhood Disadvantage on Residential Mobility in Later Life. J. Gerontol. Ser. B 2016, 71, 1131-1140. [CrossRef]

90. Kilkey, M.; Perrons, D.; Plomien, A. Gender, Migration and Domestic Work. Masculinities, Male Labour and Fathering in the UK and USA; Palgrave Macmillan: Hampshire, UK, 2013.

91. King, R.; Warnes, A.M.; Williams, A.M. International retirement migration in Europe. Int. J. Popul. Geogr. 1998, 4, 91-111. [CrossRef]

92. Sasso, P.D.; Caliandro, L.P. The role of historical agro-industrial buildings in the study of rural territory. Landsc. Urban Plan. 2010, 96, 146-162. [CrossRef]

93. Porto, S.M.C.; Leanza, P.M.; Cascone, G. Developing Interpretation Plans to Promote Traditional Rural Buildings as Built Heritage Attractions. Int. J. Tour. Res. 2011, 14, 421-436. [CrossRef]

94. García, A.I.; Ayuga, F. Reuse of Abandoned Buildings and the Rural Landscape: The Situation in Spain. Trans. ASABE 2007, 50, 1383-1394. [CrossRef]

95. Cano, M.; Garzón, E.; Sánchez-Soto, P.J. Historic preservation, GIS, \& rural development: The case of Almería province, Spain. Appl. Geogr. 2013, 42, 34-47.

96. Barke, M.; Towner, J.; Newton, M.T. Tourism in Spain: Critical Issues; CAB International: Wallingford, UK, 1996.

97. Barbero-Sierra, C.; Marques, M.J.; Ruiz-Perez, M. The case of urban sprawl in Spain as an active and irreversible driving force for desertification. J. Arid. Environ. 2013, 90, 95-102. [CrossRef]

98. Zambon, I.; Cecchini, M.; Egidi, G.; Saporito, M.G.; Colantoni, A. Revolution 4.0: Industry vs. Agriculture in a Future Development for SMEs. Processes 2019, 7, 36. [CrossRef]

99. Zambon, I.; Cerdà, A.; Gambella, F.; Egidi, G.; Salvati, L. Industrial Sprawl and Residential Housing: Exploring the Interplay between Local Development and Land-Use Change in the Valencian Community, Spain. Land 2019, 8, 143. [CrossRef]

100. Carlucci, M.; Chelli, F.M.; Salvati, L. Toward a New Cycle: Short-Term Population Dynamics, Gentrification, and Re-Urbanization of Milan (Italy). Sustainability 2018, 10, 3014. [CrossRef]

101. Ciommi, M.; Chelli, F.M.; Carlucci, M.; Salvati, L. Urban Growth and Demographic Dynamics in Southern Europe: Toward a New Statistical Approach to Regional Science. Sustainability 2018, 10, 2765. [CrossRef]

102. Repetti, M.; Phillipson, C.; Calasanti, T. Retirement Migration in Europe: A Choice for a Better Life? Sociol. Res. Online 2018, 23, 780-794. [CrossRef]

103. Andersson, E.K.; Abramsson, M. Changing residential mobility rates of older people in Sweden. Ageing Soc. 2011, 32, 963-982. [CrossRef]

104. Chelli, F.; Rosti, L. Age and gender differences in Italian workers' mobility. Int. J. Manpow. 2002, 23, 313-325. [CrossRef]

105. Castagnetti, C.; Chelli, F.; Rosti, L. Educational performance as signalling device: Evidence from Italy. Econ. Bull. 2005, 9, 1-7.

106. Chelli, F.M.; Ciommi, M.; Emili, A.; Gigliarano, C.; Taralli, S. Assessing the Equitable and Sustainable Well-Being of the Italian Provinces. Int. J. Uncertain. Fuzziness Knowl.-Based Syst. 2016, 24, 39-62. [CrossRef] 
107. Gigliarano, C.; Chelli, F.M. Measuring inter-temporal intragenerational mobility: An application to the Italian labour market. Qual. Quant. 2016, 50, 89-102. [CrossRef]

108. Rodríguez, V. Tourism as a recruiting post for retirement migration. Tour. Geogr. 2001, 3, 52-63. [CrossRef]

109. Chelli, F.; Gigliarano, C.; Mattioli, E. The Impact of Inflation on Heterogeneous Groups of Households: An application to Italy. Econ. Bull. 2009, 29, 1276-1295.

110. Rosti, L.; Chelli, F. Higher education in non-standard wage contracts. Educ. Train. 2012, 54, $142-151$. [CrossRef]

111. Rosti, L.; Chelli, F. Self-employment among Italian female graduates. Educ. Train. 2009, 51, 526-540. [CrossRef]

112. Halbac-Cotoara-Zamfir, R.; Colantoni, A.; Mosconi, E.M.; Poponi, S.; Fortunati, S.; Salvati, L.; Gambella, F. From Historical Narratives to Circular Economy: De-Complexifying the “Desertification" Debate. Int. J. Environ. Res. Public Health 2020, 17, 5398. [CrossRef]

Publisher's Note: MDPI stays neutral with regard to jurisdictional claims in published maps and institutional affiliations.

(C) 2020 by the authors. Licensee MDPI, Basel, Switzerland. This article is an open access article distributed under the terms and conditions of the Creative Commons Attribution (CC BY) license (http://creativecommons.org/licenses/by/4.0/). 